\title{
Adverbial Subordination in Egyptian Judaeo-Arabic and Muslim Middle Arabic Versions of Qișșat al-ğumğuma from the Ottoman Period
}

\author{
Magdalen M. Connolly \\ Leverhulme Early Career Fellow, Faculty of Asian and Middle Eastern \\ Studies, University of Cambridge, Cambridge, United Kingdom \\ mmc53@cam.ac.uk
}

\begin{abstract}
In examining two Judaeo-Arabic adaptations of Qișșat al-ğumğuma 'The Story of the Skull' (Cairo JC 104 and cUL T-S 37.39) alongside two Muslim Middle Arabic versions (cul Qq. 173 and BnF Arabe 3655) from the Ottoman period, this paper explores the extent of linguistic similarities and divergences on the level of adverbial subordination, and the means through which these are expressed. It questions the long-established methodological boundaries imposed on the study of Middle Arabic, in which linguistic features of confessional varieties are generally examined in relation to Classical Arabic grammatical rules and modern spoken dialects, rather than other contemporaneous denominational varieties of written Arabic.
\end{abstract}

\section{Keywords}

Judaeo-Arabic - Muslim Middle Arabic - syntax - adverbial subordination - Qișsat alğumğuma

\section{Introduction}

The 'cultural symbiosis' of Egyptian Jewish, Muslim and Christian communities, so well reflected in the abundance of texts found in the Cairo genizah collections from the medieval era, is thought to have given way to religious segregation during the Ottoman period. These isolationist tendencies are said to be echoed in the written language of these three religious groups during this era. The number of shared genres among Muslims, Jews and Christians de-

(C) MAGDALEN M. CONNOLLY, 2020 | DOI:10.1163/2212943X-20201004

This is an open access article distributed under the terms of the CG BY 4.9 license. Brill, com04/26/2023 09:03:22AM 
creases, ${ }^{1}$ and Hebrew's linguistic influence on written Judaeo-Arabic ${ }^{2}$ grows. ${ }^{3}$ Present-day studies of this written form of Arabic reinforce these divisions by consistently examining these varieties in isolation to one another. But do these denominational delineations really reflect the linguistic reality of the period?4 Or are they merely retrospectively imposed by contemporary scholarship? ${ }^{5}$

While it is undeniable that there is a sound basis for these confessional demarcations - the use of different scripts in Judaeo-Arabic and, to a lesser extent, Christian Arabic renders written forms of the language indecipherable to those uninitiated in either religious sphere-their linguistic features are often characterised by greater similarities than differences. Furthermore, it has recently been shown that isolationist tendencies are more evident in certain Judaeo-Arabic genres than others. ${ }^{6}$ While, for instance, Judaeo-Arabic šurūh often display literary and linguistic content that is more akin to Biblical Hebrew than Muslim Arabic, ${ }^{7}$ Judaeo-Arabic folk tales of this period often share literary themes, moral teachings and religious motifs with contemporaneous Muslim and Christian Middle Arabic folk tales. Yet the question remains: to what extent are these confessional varieties of Arabic linguistically comparable?

In examining two eighteenth/nineteenth-century $\mathrm{AD}$ Judaeo-Arabic versions of Qișșat al-ğumğuma 'The Story of the Skull' (Cairo JC 104 and CUL TS 37.39) alongside two Muslim Middle Arabic versions (CUL Qq. 173 and BnF Arabe 3655 ), this paper explores the extent of their linguistic similarities and divergences on the level of adverbial subordination, and the means through which they are expressed.

While noting similarities and disparities between Judaeo-Arabic and Muslim Middle Arabic in more general linguistic features $(\S 2)$, and literary content $(\S 3)$, this paper focuses primarily on variation ${ }^{8}$ in the construction and

1 Khan, "Judaeo-Arabic."

2 The term Judaeo-Arabic is used here, as in Khan (2007), to refer to 'any form of Arabic written in Hebrew script.'

3 Hary, Multiglossia in Judeo-Arabic: With an Edition, Translation and Grammatical Study of the Cairene Purim Scroll; Translating Religion:Linguistic Analysis ofJudeo-Arabic Sacred Texts from Egypt; Wagner, Linguistic Variety of Judaeo-Arabic in Letters from the Cairo Genizah.

4 den Heijer, "On Language and Religious Identity: The case of Middle Arabic, with special reference to Christian Arab communities in the medieval Middle East," 66.

5 van Koningsveld, "Arabica-Islam," 93.

6 See Connolly, "Linguistic Variation in Egyptian Judaeo-Arabic Folk Tales and Letters from the Ottoman Period."

7 Hary, "Egyptian Judeo-Arabic Sharh — Bridging the Cultures of Hebrew and Arabic," 396-397.

8 'Linguistic variation' as it is referred to here is understood in terms of the long-standing discussion of Arabic 'diglossia' in which the 'high' (written Classical Arabic) and 'low' (spoken Arabic dialects) forms of Arabic co-exist in what has often been referred to as a dichoto- 
frequency of adverbial subordinate clauses within these two confessional varieties of Middle Arabic (§4). The comparative frequency and types of adverbial clauses are examined alongside the clause markers used to introduce them ( 4.1 and $\S 4.2$ ). The significance of the syntactic divergences displayed in the Judaeo-Arabic and Muslim Middle Arabic versions of this folk tale is brought into perspective by the analysis of equivalent syntactic constructions in contemporaneous Judaeo-Arabic letters (Rylands L192, CUL T-S 13J25.24 and CUL T-S 10J16.35) (§4.3). This leads to the conclusion that, while there is some variation in the use of subordinate constructions in the two confessional varieties of Middle Arabic, Judaeo-Arabic and Muslim Middle Arabic texts within the genre of folk tales exhibit a closer linguistic affinity (at least with regard to this feature) than exists between the language of two different contemporaneous genres of Judaeo-Arabic $(\S 5)$.

Throughout the history of written Arabic, Jewish, Muslim and Christian ${ }^{9}$ Arabic texts were commonly composed in a language that neither adheres exclusively to the strictures of Classical Arabic, nor to purely dialectal forms. It contains aspects of both, combined with 'hybrid' features, in a linguistic form generally termed 'Middle Arabic'. ${ }^{10}$ Written Middle Arabic is commonly categorised along confessional lines; Muslim Middle Arabic, Christian Middle Arabic and Judaeo-Arabic form independent areas of study, and the prevalent tendency in contemporary scholarship is to focus on only one of these confessional forms. ${ }^{11}$

The methodology pioneered by Blau, and adopted by scholars of all confessional varieties of Middle Arabic, favours the assessment of Middle Arabic

mous linguistic situation. In present-day scholarship, 'high' and 'low' are no longer viewed as the only manifestations of Arabic, but rather as two extremes of a continuum, along which many written and spoken mixed varieties are encountered. 'Variation', as it is used here, refers to these 'intermediate' or 'mixed' forms of the Arabic language. The historical, intermediate varieties of written Arabic are often termed 'Middle Arabic', while the contemporary, intermediate, spoken varieties are commonly designated 'Mixed Arabic' (Mejdell, "Playing the Same Game? Notes on Comparing Spoken Contemporary Mixed Arabic and (Pre)Modern Written Middle Arabic," 237, 244-245).

9 Due to word limitations, this article focuses only on Muslim and Jewish varieties of Middle Arabic.

10 Hary, Multiglossia in Judeo-Arabic: With an Edition, Translation and Grammatical Study of the Cairene Purim Scroll, 49; Lentin, "Middle Arabic," 216; Khan, "Middle Arabic," 817-818.

11 den Heijer, "On Language and Religious Identity: The Case of Middle Arabic, With Special Reference to Christian Arab Communities in the Medieval Middle East," 58. 
linguistic features in relation to Classical Arabic norms and contemporary vernacular varieties of Arabic. It is rare to find systematic analyses of linguistic features of two or more confessional varieties of Middle Arabic. However, if we are to understand the full nature of Middle Arabic, the extent of linguistic divergences in the writing practices of religious groups, and the diachronic shifts therein, such a study is desirable. ${ }^{12}$

In the early years of Middle Arabic studies, confessional written varieties of Arabic were generally interpreted as inferior forms of written Arabic, the product of failed attempts to write in the preferred medium: Classical Arabic. ${ }^{13}$ Middle Arabic was also understood to correspond chronologically to the medieval period. ${ }^{14}$ Both of these assertions have been widely challenged in recent scholarship. ${ }^{15}$ While it is likely that some features of Middle Arabic texts were originally the result of inadequate training in Classical Arabic grammatical standards, many commonly employed Middle Arabic features appear to have become emulated and consciously reproduced. ${ }^{16}$ It has also been demonstrated that members of both Jewish and Muslim communities composed texts in Classical Arabic alongside Middle Arabic texts, switching between the two varieties with seeming ease. ${ }^{17}$ Moreover, Middle Arabic is no longer considered to be chronologically 'middle'. The term is used instead to denote its position on a continuum, on which written Classical Arabic and spoken dialectal Arabic form the extreme points, respectively.18

12 The author has recently begun a Leverhulme Early Career Fellowship, the focus of which is a comparative study of Muslim, Jewish and Christian Middle Arabic folk tales from the Ottoman period.

13 See, e.g., Blau, The Emergence and Linguistic Background of Judaeo-Arabic: A Study of the Origins of Middle Arabic, 32, 48.

14 Ibid., 1, 6; idem, A Handbook of Early Middle Arabic, 4.

15 Lentin, "Middle Arabic," 215-216; Lentin and Grand'Henry, Moyen arabe et variétés mixtes de l'arabe à travers l'histoire; Khan, "Middle Arabic," 818; Zack and Schippers, Middle Arabic and Mixed Arabic: Diachrony and Synchrony.

16 Lentin, "Middle Arabic," 217.

17 Hary, "Middle Arabic: Proposals for New Terminology," 22, n. 10; Lentin, "Middle Arabic," 216-217; Khan, "Middle Arabic," 818; den Heijer, "On Language and Religious Identity: The case of Middle Arabic, with special reference to Christian Arab communities in the medieval Middle East," 59 .

18 Hary, Multiglossia in Judeo-Arabic: With an Edition, Translation and Grammatical Study of the Cairene Purim Scroll, 49-5o; Khan, "Middle Arabic," 817; den Heijer, "On Language and Religious Identity: The case of Middle Arabic, with special reference to Christian Arab communities in the medieval Middle East," 56. Hary, while extending the chronological period of Middle Arabic beyond the medieval era, continues to define the chronological period of Middle Arabic from the 'early Islamic period until the 18th century [AD]' (idem, "Middle Arabic: Proposals for New Terminology," 2o; idem, Multiglossia in Judeo-Arabic: With an Edition, Translation and Grammatical Study of the Cairene Purim Scroll, 52). 
The study of Middle Arabic's written varieties became increasingly popular under the aegis of Prof. Joshua Blau. Blau developed and expanded the work of D.H. Baneth, promoting the philological study of Judaeo-Arabic and establishing it as a credible, independent discipline. Blau's remarkable contributions are not limited to Judaeo-Arabic. He has produced works that examine Muslim, Christian and Jewish forms of Middle Arabic. ${ }^{19}$ Where comparisons between the confessional varieties of Middle Arabic are drawn, however, the origin, date and genre of the texts from which these examples are lifted are not always explicitly stated. This article aims, in an albeit limited manner, to develop this inter-denominational approach to the study of written Middle Arabic and to propose a more systematic methodological approach to compare different varieties.

Judaeo-Arabic is commonly categorised into three chronological periods; early (ninth - tenth centuries AD), classical (tenth-fifteenth centuries AD) and late (fifteenth-nineteenth centuries AD). ${ }^{20}$ Drawing on the numerous studies of written Judaeo-Arabic conducted so far, it is thought that JudaeoArabic spelling practices undergo consistent developments that fall into three main chronological periods: early Judaeo-Arabic spelling is generally designated 'phonetic'; while classical Judaeo-Arabic is described as 'Arabicized' based on its emulation of the graphical forms of the Arabic letters; late Judaeo-Arabic orthography-which concerns us here most-is often termed 'Hebraized' as a result of the perceived increase in Hebrew and Aramaic influences. $^{21}$

Much of the scholarship concerned with Judaeo-Arabic, including Blau's contributions, focuses on the early and classical periods of Judaeo-Arabic,

19 See, e.g., Blau, A Grammar of Christian Arabic Based Mainly on South-Palestinian Texts of the First Millennium; idem, The Emergence and Linguistic Background of Judaeo-Arabic: A Study of the Origins of Middle Arabic; idem, A Handbook of Early Middle Arabic.

$20 \quad$ Khan, "Judaeo-Arabic," 526; idem, "Middle Arabic," 825. Cf. Hary, "On Later and Modern Egyptian Judaeo-Arabic," 200-203; idem, Multiglossia in Judeo-Arabic: With an Edition, Translation and Grammatical Study of the Cairene Purim Scroll, 75-82; idem, Translating Religion: Linguistic Analysis of Judeo-Arabic Sacred Texts from Egypt, 34-37 for an alternative chronological classification of Judaeo-Arabic.

21 Idem, "Adaptations of Hebrew Script," 730; The importance attributed to Hebrew and Aramaic spelling practices on late Judaeo-Arabic orthography, to the exclusion of Muslim Arabic has recently been challenged by the findings of a detailed study of the diacritical dot's usage in late Judaeo-Arabic folk tales and letters. (Connolly, "Linguistic Variation in Egyptian Judaeo-Arabic Folk Tales and Letters from the Ottoman Period.") It is possible that Muslim Arabic may have contributed more than has previously been thought to the orthography of late Judaeo-Arabic. 
something that $\mathrm{Khan}^{22}$ and later Wagner, ${ }^{23}$ have rectified in their respective examinations of fifteenth - sixteenth- and eighteenth—nineteenth-century AD Judaeo-Arabic letters. Further, and more recent, contributions to late Judaeo-Arabic research are found in Bernstein, ${ }^{24}$ Palva, ${ }^{25}$ Edzard, ${ }^{26}$ Hasson Kenat, ${ }^{27}$ and Ørum's ${ }^{28}$ studies of Judaeo-Arabic folk tales.

\section{Qissat al-ğumğuma 'The Story of the Skull'}

Qișşat al-ğumğuma, as it is commonly referred to in Judaeo-Arabic versions of the tale, appears in Muslim Middle Arabic versions under many variations of this title; Qișsat al-ğumğuma ma'a 'İsă 'ibn Maryam 'alayhi 'al-salām 'The story of the skull with Jesus, son of Mary (Peace be upon him)' (BnF Arabe 3655), Qișșat al-ğumğuma wa-mā ğarā la-hā ma'a 'Tsā 'alayhi 'al-salām 'The story of the skull and what happened to it with Jesus (Peace be upon him)' (CUL Qq. 173), to name but a few. ${ }^{29}$ Despite the notable omission of the Prophet 'Īsā (or Jesus) in Judaeo-Arabic renditions, ${ }^{30}$ these versions of the tale follow very similar, but by no means identical, trajectories. ${ }^{31}$ Both the Jewish and Muslim versions refer to a 'person' (or Jesus) who, while walking, comes across a skull

22 Khan, "Notes on the Grammar of a Late Egyptian Judaeo-Arabic Text"; idem, "A JudaeoArabic Commercial Letter from Early Nineteenth Century Egypt"; idem, "A Judaeo-Arabic Document from Ottoman Egypt in the Rylands Genizah Collection."

23 Wagner, Linguistic Variety of Judaeo-Arabic in Letters from the Cairo Genizah; idem, "Subordination in 15th- and 16th-Century Judeo-Arabic."

24 Bernstein, Stories of Joseph. Narrative Migrations Between Judaism and Islam.

25 Palva, "A 17th-18th Century Manuscript in Spoken Egyptian Arabic: Part One: Text and Translation”; idem, “A 17th-18th Century Manuscript in Spoken Egyptian Arabic: Part Two: Linguistic Notes."

26 Edzard, "Linguistic and Cultural Features of an Iraqi Judeo-Arabic Text of the Qișas al'Anbīyā' Genre."

27 Hasson Kenat, "The Story of Zayd and Kahlā̄-A Folk Story in a Judaeo-Arabic Manuscript"; idem, "New Manuscripts in Late Judaeo-Arabic from the Firkovich Collection."

28 Ørum, 'Ușsit il-Gumguma or 'The Story of the Skull': With Parallel Versions, Translation and Linguistic Analysis of Three 19th-century Judaeo-Arabic Manuscripts from Egypt.

29 See Tottoli, "The Story of Jesus and the Skull in Arabic Literature: The Emergence and Growth of a Religious Tradition," 243-244.

30 In the Judaeo-Arabic renditions of the tale, the protagonist who speaks with the skull is simply referred to as d̄âlika al-šahṣ 'that person'.

31 One of the most notable differences between the two confessional versions of the tale is that in the Judaeo-Arabic rendition, the skull is not resurrected in order to live out a reformed and pious life on earth, as happens in the Muslim Middle Arabic versions of the tale. 
lying on the road. He entreats God to allow the skull to speak to him, so that he can question it about its life. God permits this, and thus ensues a dialogue between the two protagonists, with Jesus asking questions and the skull giving detailed responses. All four adaptations refer to the skull's life on earth-his lavish lifestyle, kingdom, armies and many wives and children. They narrate the manner of his death and his descent into hell, the meeting between the skull and the angels of death, Munkir and Nakir, the seven levels of hell, and the types of sinners that belong in each level.

The origins of Qișșat al-ğumğuma are hard to trace due to limited extant material. There is no record of the tale in existing pre- or early Islamic poetry, and no mention is made of it in the Qurān. ${ }^{32}$ However, its popularity in the Islamic tradition is evident in its far-flung dissemination in a number of Muslim countries, with renditions found in Indonesian languages ${ }^{33}$ and Turkish. ${ }^{34}$ Adaptations of the tale are also prevalent among Christians, most notably among Neo-Aramaic speakers.

The vast majority of the extant Muslim Arabic versions of the tale may be approximately dated to between the sixteenth and nineteenth centuries AD. ${ }^{35}$ In his reconstruction of the tale's literary development in the Islamic tradition, Tottoli demarcates two chronological periods as significant; pre- and posttwelfth century AD. Tottoli attributes the developments in the tale's literary content between these two periods to the composition and widespread diffusion of Farīd al-Dīn 'Atțāar's (d. c. 1220AD) Persian tale Ğumğuma nāma. ${ }^{36}$ The four manuscripts examined here belong to the latter period.

Of the two Judaeo-Arabic ${ }^{37}$ versions of this story studied here, one is from the Cairo genizah collections at the Cambridge University Library (CUL T-S Ar. 37.39), while the other is housed in microfilm form in the National Library of Israel, Jerusalem (Cairo JC 104). ${ }^{38}$ The first of these versions (CUL T-S Ar. 37.39)

$32 \quad$ Ibid., 239.

33 See Brakel-Papenhuyzen, "The Tale of the Skull: An Islamic Description of Hell in Javanese," in which the author traces the origins of the story in Indonesian languages, focusing particularly on Javanese.

34 See Pennacchietti, "Versioni cristiane e guidaide di una leggende islamica," 293.

35 Tottoli, "The Story of Jesus and the Skull in Arabic Literature: The Emergence and Growth of a Religious Tradition," 242.

36 Ibid., 240. An edition with an Italian translation of 'Ațtāar's tale may be found in Pennacchietti, "'Il racconto di Giomgiomé' di Faridoddìn Attàr e le sue fonti cristiane."

37 During a recent trip to Princeton University (where much of the Jewish Theological Seminary's genizah collection is currently being stored), I encountered another Judaeo-Arabic rendition of Qișat al-ğumğuma (JTS ENA 1275.5, 12 and 13; ENA 2700.48), an edition of which will be included in the findings of my current research project.

38 This manuscript is held in the 'Cairo Collection', which comprises approximately one 
may be approximately dated to the eighteenth - early-nineteenth century AD. The extant manuscript is incomplete, lacking both the beginning and end of the story. It comprises three leaves, on which both the recto and verso each contain between 20 and 25 lines of writing. With the exception of some small holes on 3verso, the manuscript is in good condition. The second version of this story (Cairo JC 104), which survives in excellent condition and in full, is explicitly dated to $1887 \mathrm{AD}$. A transcription and English translation of the latter manuscript has recently been published by Ørum. ${ }^{39}$

With regard to the Muslim ${ }^{40}$ Middle Arabic texts, ${ }^{41}$ one of the manuscripts (CUL Qq. 173) is dated to 1703 AD, and was bequeathed to the Cambridge University Library by Johann Ludwig Burkhardt, the Swiss traveller and Arabist. At the beginning of the volume of collected manuscripts, in which this particular rendition is encountered, there is a small Arabic inscription stating that these are hikāyāt fi lugiat mișr 'tales in the language of Egypt'. Both the origin and date of the second Muslim Middle Arabic version of this folk tale (BnF Arabe $3655)$, now housed in the Bibliothèque Nationale de France, are uncertain. It has been loosely dated to between 1700 and $1800 \mathrm{AD}$, but no reference is made to its geographical origin. ${ }^{42}$

In general, Judaeo-Arabic adaptations of this tale appear to be more recent compositions than the Muslim Middle Arabic versions. This may be because the narrative was adopted and adapted in the Jewish tradition later than in the Muslim tradition. It is worth noting, however, that there is a marked reduction in the number of texts deposited in the Ben Ezra synagogue's genizah after the thirteenth century. Many of the Jewish elite moved from Fustat to Cairo during the thirteenth century, which resulted both in the synagogue's physical decline, and a decrease in texts being deposited in its genizah. Thus, the texts we have at our disposal may not be fully representative of the extent of Jewish engagement with Muslim and Christian culture.

hundred Egyptian Judaeo-Arabic and Hebrew manuscripts. They are currently housed in microfilm form in the National Library of Israel, Jerusalem. The majority of the collection is Judaeo-Arabic šurūḥ (Biblical translations and commentaries), but it also contains a small number of Judaeo-Arabic folk tales (Hary, "Cairo Collection," 533-534).

39 Ørum, 'Ușsit il-Gumguma or 'The Story of the Skull': With Parallel Versions, Translation and Linguistic Analysis of Three 19th-century Judaeo-Arabic Manuscripts from Egypt.

40 These tales are identified as Muslim by the fact that each contains at least one recitation of both the first and second šahādāt.

41 As far as I am aware, no critical edition of either of these Muslim Middle Arabic texts is currently available.

42 BnF Arabe 3655 is available to view online: http://gallica.bnf.fr/ark:/12148/btvıb11oo30485/ fio8.item.zoom. 
In explorations of subordination found in late Judaeo-Arabic folk tales and letters (e.g., BnF Hébreu 583) in my Ph.D. research, two aspects of adverbial subordination found in these two Judaeo-Arabic genres (among many) have struck me as particularly noteworthy. The first of these is the importance of the complementiser in differentiating the function of prepositions as heads of adverbial subordinate clauses from their functions as heads of prepositional phrases with nominal dependents. The second aspect concerns the relative frequency of temporal and purposive adverbial clauses in Judaeo-Arabic letters and folk tales. These types of adverbial clauses are far more common in the latter than in the former. It is possible that this is a result of the tales' descriptive function, as opposed to the letters, which are primarily concerned with communicating facts, figures and (thinly veiled) commands. This paper offers a rare opportunity to expand this particular aspect of my Ph.D. research, combining it with a related interest in the linguistic features of contemporaneous Muslim Middle Arabic folk tales, and the as yet under-explored linguistic similarities between the two confessional varieties.

Adverbial clauses are hypotactic; ${ }^{44}$ they do not carry equal status to that of the main clause, but instead furnish the main clause with additional detail(s). ${ }^{45}$ An adverbial clause may modify either the verb in a main clause or the main clause in its entirety. ${ }^{46}$ They may be finite, non-finite or verb-less. ${ }^{47}$ In Arabic as in English, finite adverbial clauses occur more frequently than non-finite and verb-less clauses. ${ }^{48}$ In relation to the main clause, adverbial clauses most commonly occur pre-positionally in Arabic.

Adverbial clauses are often divided into two categories: those that may be supplanted by an adverb (temporal, locative and manner clauses); and those

This paper is based, in part, on research conducted for my Ph.D. thesis (Connolly, "Linguistic Variation in Egyptian Judaeo-Arabic Folk Tales and Letters from the Ottoman Period"). Hypotaxis is also referred to as 'co-subordination' (see Olson, "Barai Clause Junctures: Towards a Functional Theory of Interclausal Relations”; Van Valin, "A Typology of Syntactic Relations in Clause Linkage," 546). It refers to a type of clause structure that is dependent on the main clause, but not embedded (Häcker, Adverbial Clauses in Scots: A SemanticSyntactic Study, 21; Aarts, "Subordination," 252). What constitutes an 'embedded' clause is, however, much contested (Häcker, Adverbial Clauses in Scots: A Semantic-Syntactic Study, 22).

45 Ibid., 21.

46 Thompson, Longacre, and Hwang, "Adverbial clauses," 238.

47 Häcker, Adverbial Clauses in Scots: A Semantic-Syntactic Study, 26; Popa, "Non-finite and Verbless Clauses: Textual Values," 33 o. Ibid. 
that may not (such as purposive, causal, concessive and conditional clauses). ${ }^{49}$ Of the first category, temporal adverbial clauses occur more frequently in the Judaeo-Arabic and Muslim Middle Arabic texts under consideration than locative or manner adverbial clauses. Location and manner are expressed with relative clause constructions, adverbs or adverbial phrases rather than adverbial clauses. With regard to the second category, this paper focuses on purposive adverbial clauses.

The following discussion concentrates on (i) the types of adverbial clauses that occur in this Judaeo-Arabic and Muslim Middle Arabic folk tale; (ii) the frequency of adverbial clauses per text, and (iii) the formal complexity and semantic functions of clause markers used to introduce adverbial clauses in these texts. Comparisons are also drawn from contemporaneous Judaeo-Arabic letters in order to contextualise the findings.

\subsection{Temporal Adverbial Clauses}

As Arabic displays a rich variety in its markers of temporal adverbial clauses, those discussed here are initially categorised according to the type of semantic connection (i.e. the English equivalents of 'when', 'until' or 'after') that they express. Once established, the frequency of adverbial clauses and the nature of subordinators used to introduce them are discussed in greater detail. The expansion of the main clause by temporal adverbial clauses in the JudaeoArabic and Muslim Middle Arabic manuscripts under consideration here falls into three distinct categories:

§ 4.1.1. Adverbial clauses in which the onset of the event/action of the main clause is either (i) simultaneous in time or (ii) immediately following the event/action in the adverbial clause (in italics). An example of the former is: 'When I heard it, I understood.' Whereas, in the following example, the onset of the main clause's event/action occurs immediately after the event/action of the adverbial clause: 'When he came into the room, I left. 50

§4.1.2. Adverbial clauses that specify 'up to the time that; to the point or degree when' an event/action in the main clause occurs (i.e. 'until'). ${ }^{51}$

§ 4.1.3. Adverbial clauses that explicitly mark the fact that an event/action in the main clause follows the onset of an event/action in the adverbial clause, e.g., 'After he came, I left.'

\footnotetext{
49 Thompson, Longacre, and Hwang, "Adverbial clauses," 243-245.

50 I am grateful to Prof. Geoffrey Khan for clarifying this issue, and for providing me with these examples.

$5^{1}$ OED online: http://www.oed.com/ og/o8/17.
} 
4.1.1 'When'52

The simple subordinator $1 m^{\prime}$ ' (= CA: $\operatorname{lamm}^{53}$ ) 'when' is the most common marker of temporal adverbial subordinate clauses in both the Judaeo-Arabic ${ }^{54}$ and Muslim Middle Arabic versions of the tale. This subordinator occurs eight times in total in Cairo JC 104 and five times in (the incomplete) T-S Ar. 37.39, while it appears nine times and fourteen times in the Muslim Middle Arabic versions BnF Arabe 3655 and cul Qq. 173, respectively. In the following examples, we find several instances in which the use of the subordinator lamma does not deviate from the standard Classical Arabic usage. ${ }^{55}$ The subordinator precedes a verb in the suffix conjugation, and the onset of the main clause is occasionally marked with the bound particle $f y$-/fe- (= CA: $f a-)$ 'so, thus', e.g.,

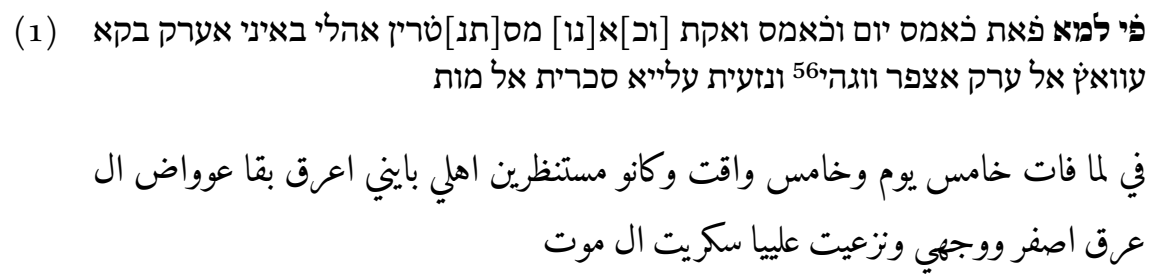

And when a fifth day and a fifth moment had passed, my people were expecting me to perspire, but instead of sweating, my face become pale and the agony of death came upon me.

T-S Ar. $37 \cdot 39,1^{\mathrm{r}} \cdot 19-\mathbf{1}^{\mathrm{v}} .1$

פלמא פאת עלייא ذאמס יום וכאמס וקת וכאנו מסתנטרין אלגמאעה אנני אערק בקא (2)

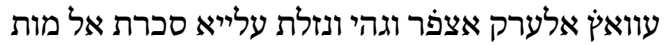

$5^{2}$ In the following transcriptions, curly brackets $\{\ldots\}$ are used to indicate superscription of a word or words in the original text. Square brackets $[. .$.$] indicate lacunae in the original$ manuscript. Parentheses (...) are used in the translation to indicate words that have been included to aid comprehension.

53 The equals sign '=' is used here to indicate the equivalent Classical Arabic (CA) form.

54 All Judaeo-Arabic examples used here are transcribed grapheme-for-grapheme into Arabic script in order to make them accessible to a wider audience.

55 It is rare to find the apodosis introduced - as is common, but by no means obligatory in Classical Arabic — with the bound particle $f y$ - $/ f e^{-}$-'so, thus' (= CA: $\left.f a-\right)$ in either the JudaeoArabic or Muslim Middle Arabic versions of the tale.

$5^{6}$ It is not uncommon in Late Judaeo-Arabic folk tales from the eighteenth and nineteenth centuries to find double vav, denoting consonantal /w/, geminated /ww/, and the diphthong /aw/ in word-initial, medial and final positions (See Connolly, "Linguistic Variation in Egyptian Judaeo-Arabic Folk Tales and Letters from the Ottoman Period," 72-73). This phenomenon is attributed to Rabbinic Hebrew orthographic influence. 


$$
\text { العرق فات علييا خامس يوم وخامس ونزت وقت وكانو مستنظرين الجماعه انتي اعرق بقا عوواض }
$$

And when a fifth day and a fifth moment passed, the group was expecting that I would perspire, but instead of perspiring, my face grew pale and the agony of death fell upon me.

Cairo JC 104, $5^{\mathrm{v}} \cdot 12-16^{\mathrm{r}} \cdot 3$

فلما كان في اليوم الثامن اصبحت مفاصلي ترتعش وركبتي ترتعد ولساني معلق في سقف (3)

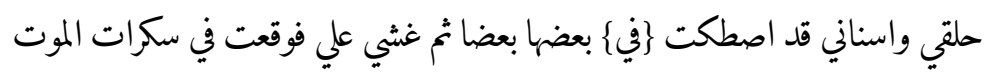

And when the eighth day (came), my joints began to shake (with fear) and my knees trembled, my tongue was sticking to the roof of my throat and my teeth chattered against one another. Then, I fainted and I plunged into the agonies of death.

CUL Qq. 173, 151 ${ }^{\mathrm{r}}$. 6-10

(4)

$$
\text { فلما كان اليوم الخامس اشتد مابي وارتعدت فرايصي وغارت عيناي ووقعت في سكرات }
$$

And when it was the fifth day, what was (wrong) with me intensified and my whole body trembled with fear, my eyes became hollow and I fell into agonies.

BnF Arabe $3655,112^{\mathrm{v}} .2-4$

(5למא פאק מן גְשוותו בכי דَאלך אלשכץ בוכא עטים ושהק שהקא עצימה ועאד גִושי (5)

$$
\text { فلما فاق من غشووتو بكي ذالك الشخص بوكا عظيم وشهق شهقا عظيمه وعاد غوشي }
$$

When he awoke from his fainting fit, that man wept many tears and sighed very deeply, then he fainted a second time.

Cairo JC 104, 14․ 10-11

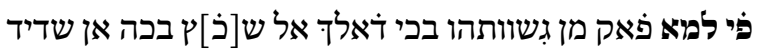

$$
\text { في لما فاق من غشووتهو بكي ذالك ال شخص بكه ان شديد }
$$

And when he woke from his fainting fit, that man cried bitterly.

T-S Ar. $37 \cdot 39,3^{\mathrm{r}} \cdot 3^{-4}$ 


$$
\text { واني لما عاينت ذلك يا روح الله بكيت علي نفسي بكا شديداً }
$$

And indeed, when I saw that, O spirit of God, I cried vehemently for myself.

CUL Qq. 173, 155 $\cdot 2-4$

$$
\text { فلما سمع عيسي عليه السلام ذلك بكي بكا شديدا }
$$

And when Jesus (Peace be upon him) heard that, he wept bitterly. BnF Arabe $3655,114^{\mathrm{r}} \cdot 15^{-16}$

פּי למא סמע דَאלך אלשכץ דאלך אלאמור כולהא אלדי נטקת פיהום אלגמגמה וקע (9) וֹגִושי

$$
\text { في لما سمع ذالك الشخص ذالك الامور كولها الذي نطقت فيهوم الجمجمه وقع وغوشي }
$$

And when that man heard all of those things that the Skull spoke about, he fell and fainted.

Cairo JC 104, 14v. 8-10

פללמא פרג דאלך אל אנסאן מן כלאמו ואדה קד אמרהא אללאלק סות"57 עז וגל אנהא (10) תגאווב פי גמיע מא יסאלהא ויטלוב מנהא

$$
\text { فملما فرغ ذالك ال انسان من كلامو واذه قد امرها الخالق سوت" عز وجل انها تجاووب في }
$$

And when this man had finished his speech, then the Creator, may He be glorified and exalted, (the) Exalted and Sublime, commanded it to answer everything he asked it and requested of it.

Cairo JC 104, $3^{\mathrm{r}} \cdot 4^{-8}$

فلما سمع عيسي عليه السلام منها هذا الكلام تعجب وقال لها اخبريني يا جمجمة كيف رايتي (11) الموت وصعوبته

57 subhānahu wa-ta'ālā '[God,] Glory be to Him, and may He be exalted’ סות. 
And when Jesus (Peace be upon him) heard these words from it, he was astonished, and he said to it, 'O, skull! What did you see of death and its tribulation(s)?' CUL Qq. $173,15^{0^{v}} \cdot 9^{-12}$

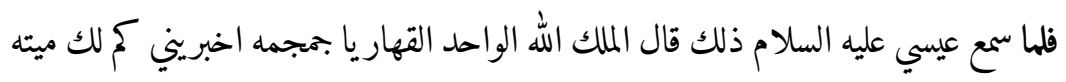

And when Jesus (Peace be upon him) heard that, he said 'The king, God is The One, the Vanquisher! O skull! Tell me how long you have been dead?' BnF Arabe $3655,112^{\mathrm{r}}$. $12-13$

In a deviation from the Classical Arabic norm, the subordinator lammā occurs in a construction with a complementiser. While a similar construction does occur in Classical Arabic, the complementiser 'an 'to'58 - as opposed to 'anna 'that' found here-is used. The addition of the complementiser does not affect the semantic function of the subordinator. However, it does attest to the tendency, evident here — and in contemporaneous Judaeo-Arabic folk tales ${ }^{59}$ - to include a complementiser in order to explicitly mark the function of the subordinator as that of head of an adverbial clause, ${ }^{60}$ e.g.,

58 Fischer, A Grammar of Classical Arabic: Translated from German by Jonathon Rodgers, 226, $\S 443$.

59 My interest in adverbial subordination and subordinators was sparked by a contemporaneous nineteenth-century AD Judaeo-Arabic manuscript - BnF Hébreu 583 -in which adverbial clauses introduced with complex subordinators that take a complementiser abound, e.g.,

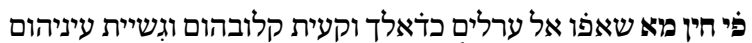

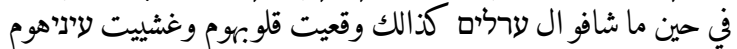
'When the uncircumcised saw this, it stopped their hearts and clouded their sight.' (BnF Hébreu 583, 68-69).

In one case in this manuscript, the opacity in the function of $m \bar{a}$ (which may be interpreted as either a free relative particle or a complementizer in a given context) is extended to the relative pronoun 'alladi $\bar{l}$, which here is used as a complementizer in the construction $f y+h y n+' l d y$, as the head of an adverbial clause, e.g.,

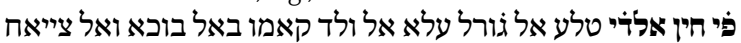

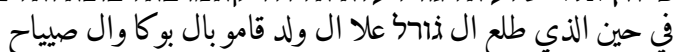
'When the lot fell on the boy, they began weeping and wailing ...' (BnF Hêbreü 583, 8-10) (see Connolly, "A Nineteenth-Century Egyptian Judaeo-Arabic Folk Narrative:Text, Translation and Grammatical Notes" for a detailed discussion of this phenomenon).

6o This may result from the analogical extension of the tendency in Judaeo-Arabic folk tales to mark prepositional constructions acting as head of an adverbial clause with a complementiser. This practice may have been further applied to other subordinators used to introduce adverbial clauses. 

למא אנגי וצלת לבאב גהינם פי ראית עלה באב גהינם שיך כביר מוחתרם

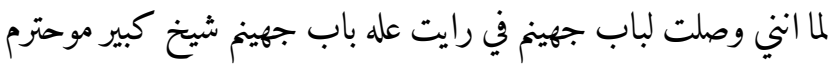

When I arrived at the gate(s) of hell, I saw a great, respected man on the gate(s) of hell.

Cairo JC 104, $11^{\mathrm{r}}$. 11-14

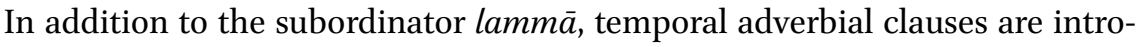
duced with lexically-derived subordinators such as $f y+w q t+m^{\prime}$ (= CA: lammā) found in the following two examples (14 and 15). This subordinating construction is semantically synonymous with the subordinator lammā in that it marks the event in the main clause as occurring immediately after the event/action in the adverbial clause:

פיי וקת מא סמע דאלך אלשכץ מא תועדא עלה תלך אלגמגמה קאל לא חולא ולא קותא (14) אלא באללה אלעאלי אלעטים

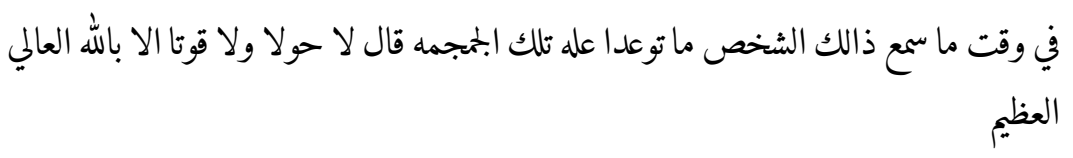

And when that man heard what had been done to this skull, he said, 'there is no strength or power save in God, the Almighty!'

Cairo JC 104, $12^{\mathrm{r}} \cdot 3^{-6}$

פִי יאקת מא סמע דאליך אל שכץ גמיע מא תועדה עלא דָאלך אל גמגמה לא חולא ולא (15) קווא אלא באללה אל עאלי אל עטים

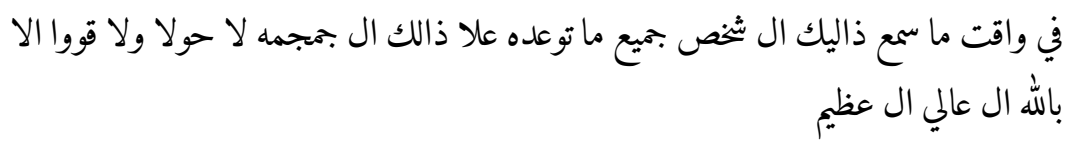

And when that man heard all that had been done to this skull, (he said,) 'There is no strength or power save in God, the Almighty, the Great!'

T-S Ar. $37 \cdot 39,2^{\mathrm{r}} \cdot 4^{-6}$

While the simple subordinator lammā is undoubtedly the most frequent marker of this type of temporal adverbial clause in all four texts, in the Judaeo-Arabic versions there is evidence of complex subordinators which take a complementiser when acting as the head of adverbial clauses that are notably absent in the two Muslim Middle Arabic versions. 
4.1.2 'Until'

In both Cairo JC 104 and T-S Ar. 37.39, 'until' is expressed with the subordinator $h t^{\prime} / h t h$ (= CA: hattā), which appears both with and without the bound morpheme particle $l$ - (= CA: $l i-)$. The addition of the bound particle does not appear to affect the subordinator's semantic or syntactic functions. However, it may be indicative of the Judaeo-Arabic writers' tendency to embellish simple subordinators with the addition of a preposition or complementiser. In the Muslim Middle Arabic versions of the tale, hattā appears without the particle $l i$-, in accordance with Classical Arabic convention. In all four manuscripts, the subordinator precedes both suffix and prefix conjugations, e.g.,

כאן אללה סו61 יג[דד] לי גלד גִירו62 חתא אקצר אתבית עלא עדאבי

$$
\text { كان الله سو يجدد لي جلد غيرو حتا اقضر اتبيت علا عدابي }
$$

God — may He be praised — was renewing my skin, and so forth, until I was able to withstand my punishment.

T-S Ar. 37.39, $3^{\mathrm{r}} \cdot 9^{-11}$

תום חמלוני אלא גהנם ושחטאטוני63 עלא וואגהי לחתא וצלת לגהנם

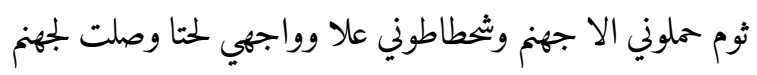

Then, they carried me to hell, and they dragged me on my face until I arrived at hell.

T-S Ar. $37 \cdot 39,3^{\mathrm{v}} \cdot 16-17$

כאן אללה סות" יגדד לי גלד גִירו חתא אקדר אתבת עלה דָאלך אל עדאב

$$
\text { كان الله سوت" يجدد لي جلد غيرو حتا اقدر اتبيت عله ذالك ال عذاب }
$$

61 subhānahu 'glory be to Him' סו 6.

62 In some instances, the 3.m.sg. pronoun (CA: -hu/-hi) is represented not with its equivalent grapheme heh, as in Classical Judaeo-Arabic, but with vav. This reflects the colloquial pronunciation $-u$. In Late Judaeo-Arabic texts, this phenomenon is more common in eighteenth/nineteenth-century letters than in contemporaneous folk tales (Connolly, "Linguistic Variation in Egyptian Judaeo-Arabic Folk Tales and Letters from the Ottoman Period," 85).

63 ושחטאטוני :and they dragged me' (ECA: šahțtat 'to drag, lug' Hinds and Badawi, A Dictionary of Egyptian Arabic: Arabic-English, 454). 
God - may He be praised — was renewing my skin, and so forth, until I was able to withstand that punishment.

Cairo JC 104/15 $\cdot 9^{\mathrm{r}}-11$

ויעמלו כדה לחתה אקדם אתבת עלה עדאבי

$$
\text { ويعملو كده لحته اقدم اتبت عله عذابي }
$$

And they did this until I was able to withstand my punishment.

Cairo JC 104/13 v $\cdot 11-12$

(20)

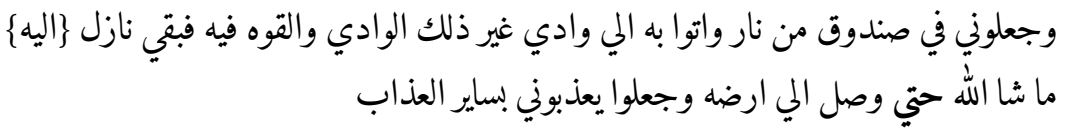

Then, they put me in a box made of fire, and they brought it to another valley, and they threw it down there. It continued descending ${ }^{64}-$ How long soever God intends - until it reached its ground. Then, they began to torture me with the rest of the punishment.

BnF Arabe $3655,115^{\mathrm{v}} \cdot 9^{-12}$

$(21)$

$$
\text { فهويت الي الارض ما شا الله تعالي فعصرتي الارض حتي ادخلت بعضي في بعض }
$$

I tumbled to the ground - whatever God, the Almighty wills - and the ground crushed me until I was compressed (lit. part of me was made to enter).

CUL Qq. $153^{\mathrm{r}} \cdot 10-11$

$$
\text { فا استتم دعاه حتي نزل جبريل عليه السلام }
$$

And he did not cease his plea until Gabriel (Peace be upon him) descended.

CUL Qq. 173, 149 $.1-2$

$$
\text { فما استتم عيسي عليه الاسلام كلامه حتي سمع الندا من قبل العالي العُلا الاعلي }
$$

And Jesus (Peace be upon him) did not cease his words until he heard the call from the Sublime, the highest height ...

BnF Arabe $3655,110^{v} .14-16$

64 Form III = 'to clash/argue with someone'. 
All four adaptations of the tale favour the simple Classical Arabic subordinator hattā to introduce this type of temporal adverbial clause. However, there are glimpses in the Judaeo-Arabic examples of the tendency to embellish the simple subordinator, which, yet again, are not evident in the Muslim Middle Arabic versions. Temporal adverbial clauses of this kind occur marginally more frequently in the two Muslim Middle Arabic tales than in the Judaeo-Arabic renditions.

4.1.3 'After'

The complex subordinator $b^{\prime} d m^{\prime}$ (= CA: $b a^{\prime} d a m \bar{a}$ ) appears in each of the Judaeo-Arabic manuscripts to introduce adverbial clauses, but does not occur in the Muslim Middle Arabic texts, e.g.,

ובעד מא אסקוני אתנתר לחמי ולחם ווגה ואתקטעית גלודי מן עלא כדודי

$$
\text { وبعد ما اسقوني اتنتر لحي ولحم ووجه واتقطعيت جلودي من علا خدودي }
$$

And after they made me drink (it), my flesh and the flesh of (my) face was scattered (from my bones), and my skin was hacked off from my cheeks.

T-S Ar. 37.39, 2v . 9-11

ובעי[ד מ] א אסקוני אתנתר לחמי ולחם וגְהי ואתקטעת גלודי מן עלה לחמי

$$
\text { وبعد ما اسقوني اتنتر لحمي ولحم وجهي واتقطعت جلودي من عله لحمي }
$$

And after they made me drink, my flesh and the flesh of my face fell off and my skin was hacked off from my flesh.

Cairo JC 104, 13‥ 6-8

Bada occurs in the Muslim Middle Arabic texts only as the head of prepositional phrases with nominal dependents, but not as the marker of an adverbial clause. The equivalent sections of the narrative are expressed in the two Muslim Middle Arabic versions of this text with the simple subordinator $l m^{\prime}$ ' = CA: lammā) (see CUL Qq. 173), and the lexically-derived subordinator hyn (= CA: hina; ECA hin) (see BnF Arabe 3655) without the addition of a complementiser, e.g.,

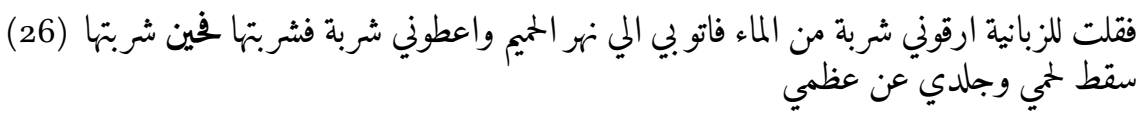


So, I said to the myrmidons, 'raise me up a drink of water!' So, they brought me to the river of poison, and they gave me a drink, so I drank it. When I drank it, my flesh and my skin fell from my bones.

BnF Arabe $3655,114^{\mathrm{v}} \cdot 7^{-10}$

(27)

فقلت للزبانيه اسقوني فسقوني شربة من الحيم فلما رشربتها\{ تمزقت جلودي فاعادها الله كما

So, I said to the myrmidons 'give me a drink!' So, they gave me a drink of poison. When I drank it, my flesh fell off. Then God restored it to what it had been before.

CUL Qq. $173,155^{\mathrm{r}} \cdot 8-10$

\subsection{Purposive Adverbial Clauses}

In the Judaeo-Arabic manuscripts under consideration here, purposive adverbial clauses are-as is common in contemporaneous folk tales such as $\mathrm{BnF}$ Hébreu 583 - expressed with a prepositional construction which takes the complementizer $m$ ' (= CA: $m \bar{a}$ or 'anna/'an), e.g.,

פאל חין אנגמעו גמיע אלחוכמה ואלאטיבה לאגל אגהום ידאווני

$$
\text { فال حين انجمو جميع الحوكمه والاطيبه لاجل انهوم يداووني }
$$

Then all the sages and physicians gathered so that they (could) treat me. Cairo JC 104/5v. 8-10

פי אל חין אסתגמעו אל חוכמה ואל אטיבה לאגל מא ידווני

$$
\text { في ال حين استجمعو ال حوكمه وال اطيبه لاجل ما يدووني }
$$

Then they gathered the sages and the physicians so that they could treat me.

T-S Ar. $37 \cdot 39,1^{\mathrm{r}} \cdot 13^{-14}$

In the corresponding passages in the two Muslim Middle Arabic versions of the tale, the purposive sentiment is expressed using the simple, bound subordinator $l$ - 'in order to' (= CA: $l i-)$ in the former, and is absent in the latter: 
(30)

$$
\begin{aligned}
& \text { ومملت الي قصري وو\}ضعت علي سريري فلما اصبحت اتوني بكل حكيم في مدينتي كلا }
\end{aligned}
$$

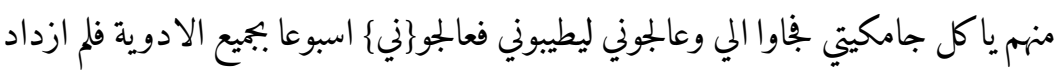

$$
\begin{aligned}
& \text { الا وجعا ومرضا }
\end{aligned}
$$

And I was carried to my palace and I was laid down on my bed. When I awoke, they brought every sage in my city, each one of whom was on my pay role (lit. 'consumes my pay'). So, they came to me and they treated me in order that they might cure me. They tended to me for a week with all the medicines, but I only increased in pain and sickness.

CUL Qq. 173, 151 $1^{\mathrm{r}}$. 1-6

فحملوني واخرجو\}ني\{ باثوابي الي قصري ووضعوني علي فراشي فبقيت علي تلك الحالة اربعة (31)

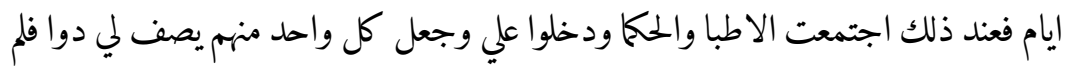
يزدني دواهم الا حصر

And they carried me, and they took me out in my clothes to my castle and they placed me on my bed. I stayed in this state for four days. With that, the physicians and the sages gathered, and they came to me, and each one of them began to prescribe me a medicine, but their medicine only increased the dyslogia.

BnF Arabe $3566,112^{\mathrm{r}} \cdot 17-112^{\mathrm{v}} \cdot 2$

In both the Judaeo-Arabic manuscripts Cairo JC 104 and T-S Ar. 37.39, we find an alternative complex subordinator acting as head of purposive adverbial clauses. In this construction, the Classical Arabic-derived, multi-functional subordinator h $t^{\prime}$ (= CA: hattā) occurs with the complementisers ' $n$ (= CA: 'an) or 'nn (= CA: 'anna), forming $l-+h t^{\prime}+$ 'n/'nn 'so that, in order to/that' (= CA: li-'ağli 'an), e.g.,

אללה תועאלה יתבארך אסמו אלדי פכאני מן דאלף אלעדאב לחתא און אגאוובף עלה (32)

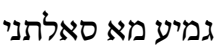

$$
\text { الله توعاله يتبارك اسمو الذي فكاني من ذالك العذاب لحتا ان اجاووبك عله جميع ما سالتني }
$$

God, the Almighty, blessed be His name, who released me from that punishment so that I could answer you all that you asked me.

Cairo JC $104 / 15^{\mathrm{v}} \cdot 5^{-8}$ 
פ[י] צובחאן אללה תוע65 אלדי פכני [מן] דאלך אל עדאב לחתא אני אגוובך עלא גמיע (33) מא [סאלתני]

$$
\text { في صوبحان الله توع الذي فكني من ذالك ال عداب لحتا اني اجووبك علا جميع ما سالتني }
$$

And praise be to God, the exalted, who untied me from that punishment so that I could answer you all that you asked me.

T-S Ar. $37 \cdot 39,3^{r} \cdot 14-15$

This subordinator minus the complementiser (i.e. $\left.l-h t^{\prime}\right)$ is used elsewhere in these two folk tales (see examples 17 and 19) to introduce 'until' clauses. It would appear, therefore, that whereas in Classical Arabic the semantic function of the subordinator hattā may be divined only from the immediate context, in eighteenth/nineteenth-century AD written Judaeo-Arabic, a complementiser was consistently inserted into the construction when introducing purposive adverbial clauses, distinguishing between its various semantic functions and aiding comprehension. This complex subordinator is entirely absent in the Muslim Middle Arabic renditions of the folk tale.

In one instance in the Judaeo-Arabic manuscripts Cairo JC 104 and T-S Ar. 37.39 (examples 34 and 35), the overwhelming preference for introducing purposive adverbial clauses with complex subordinators is supplanted by the simple bound preposition $l-+1 . c . s g$. prefix conjugation verbal forms (= CA: li- + subjunctive):

וכונת יום דذלת ללחמאם לנסתחמא פִי דוذת גוא אלחמאם ווקעת וגְושית

$$
\text { وكونت يوم دخلت للحمام لنستحما في دوخت جوا الحمام ووقعت وغوشيت }
$$

One day, I was entering the hammām in order to bathe, thereupon I became dizzy inside the hammām and I fell and fainted.

Cairo JC 104/5 $5^{\mathrm{r}} \cdot 13^{-15}$

וכונת יום דכלת לל חמאם לנתגְסיל פי אכדתני אל סכרא וגְשיה פִי אל חמאם

$$
\text { وكونت يوم دخلت لل حمام لنتغسيل في اخدتني ال سكرا وغشيه في ال حمام }
$$

And (one) day, I was entering the hammām in order to bathe (when) intoxication seized me and I fainted in the hammām.

T-S Ar. $37 \cdot 39,1^{\mathrm{r}} \cdot 12-13$

65 tacālā ‘God,] may He be exalted' תוע. 


\subsection{Adverbial Subordination in Judaeo-Arabic Letters}

In order to gain perspective on the frequency of adverbial clauses and variances displayed in the use of adverbial subordinators in the Judaeo-Arabic and Muslim Middle Arabic texts discussed above, it is worth examining examples of adverbial clauses and subordinators in contemporaneous Judaeo-Arabic letters. Drawing examples from three eighteenth-century AD Judaeo-Arabic letters-CUL T-S 10J16.35, ${ }^{66}$ CUL T-S $13 \mathrm{~J}_{25} 5.24,{ }^{67}$ and Rylands L192 ${ }^{68}$ —demonstrates that while there are differences in the use of simple and complex subordinators in the Judaeo-Arabic and Muslim Middle Arabic folk tales, the frequency of adverbial clauses is far greater in this shared genre, than in the genre of Judaeo-Arabic letters.

\subsection{1 'When'}

Adverbial clauses expressing a temporal connection with the main clause occur only in the letter T-S 13J25.24. In this text, neither the Classical Arabic-derived particle $l m^{\prime}$ ( = CA: lammā) nor complex subordinators occur, which appear in both the Muslim Middle Arabic and Judaeo-Arabic folk tales. Instead, we find several examples of the substantive-derived subordinator hyn (= CA: hina; ECA: hìn) used to introduce adverbial clauses denoting 'when' an action or event occurred. The subordinator hyn (which appears once in the Muslim Middle Arabic folk tale BnF Arabe 3655 , see example 26) is used regularly in colloquial Egyptian Arabic to introduce adverbial clauses, e.g.,

ולם עטאהום לנה ובעדו חין גאנה ישטראך מיננה קולנ לו אחנה לם נשארכו חד

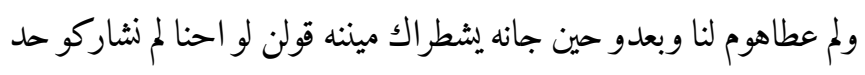

... but he did not give them to us. Afterwards, when he came to us to take a share from us, we said to him that we will not share with anyone ...

T-S 13J25.24, col. 1, 10-11

66 As yet, a transcription and translation of CUL T-S 10J16.35 has not been published in full, however, it is referred to by Wagner in her extensive analysis of Judaeo-Arabic letters (Linguistic Variety of Judaeo-Arabic in Letters from the Cairo Genizah).

67 Khan ("A Judaeo-Arabic Commercial Letter from Early Nineteenth Century Egypt") has produced a critical edition of this text, with a transcription, translation into English and grammatical notes.

68 Khan ("A Judaeo-Arabic Document from Ottoman Egypt in the Rylands Genizah Collection") has produced a transcription, English translation and linguistic commentary of the manuscript Rylands L192. 
פי כדה חין טוסלכום69 תתפעוהא ${ }^{70}$ ותרסלו לנה רגעתהא

$$
\text { في كده حين طوسلكوم تتغعوها وترسلو لنا رجعتها }
$$

So, when you receive it, pay it and send us the receipt for it.

T-S 13J25.24, col. 2, 4

וכדה חין יוסלכום אל סבב ביל סלאמה לם תסתעגלו עליה

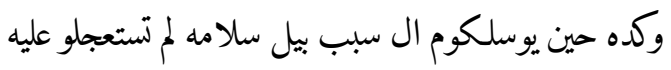

And so, when the assignment reaches you safely do not be hasty with it ...

T-S 13J25.24, col. 2, 40-41

ולאכין חין יחצר לכום חיסבכום ותתללסו עלא אל צאף בעה ימכין נרסלו סבובה בינתנה (39)

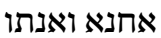

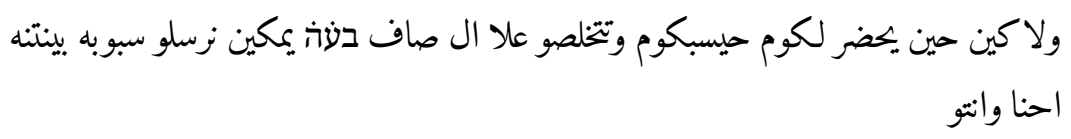

But when he presents you with your accounts and you acquire the net proceeds, God willing, we will be able to send goods to one another.

T-S 13J25.24, col. 2, 27-30

\subsection{2 'Until'}

Temporal adverbial clauses denoting 'until' are also scarce in these eighteenth/ nineteenth-century AD letters. I have identified only one instance of this type of temporal adverbial clause, in which the Classical Arabic-derived subordinator $h t^{\prime}$ 'occurs in conjunction with the Classical Arabic-derived particle 'd $h$ (CA: 'id $\underline{a}$ ), a construction often found in Classical Arabic texts, e.g.,

69 This is an instance of simultaneous tafhim and tarqiq, in which the 2.m.pl. prefix $t$ (CA: $t u-)$ is represented by Hebrew tet, while the radical șâd is denoted with Hebrew $\sin$.

70 The representation of Arabic dāl with Hebrew tav here suggests devoicing, and partial assimilation. 
He stayed until they became unreliable.

$\mathrm{T}-\mathrm{S} 1 \mathrm{JJ} 16.35, \mathrm{1}^{\mathrm{r}}$. margin 3

\subsection{3 'After'}

As with all other forms of temporal adverbial subordination examined so far in these late Judaeo-Arabic letters, clauses referring to the point 'after' an event or action took place are extremely infrequent. Finite temporal adverbial clauses denoting 'after' do not occur in T-S 13J25.24, Rylands L192 or T-S 10J16.35. However, there is one instance in the letter T-S 13J25.24 in which a non-finite clause appears:

וחסבנה עלא تע שVI אל ריאל ועטאנה פולסה באלפ ותמניה •ץ רייאל פרנסה לבעד (41) וסולהא ליידכום בעשר תייאם אליאל

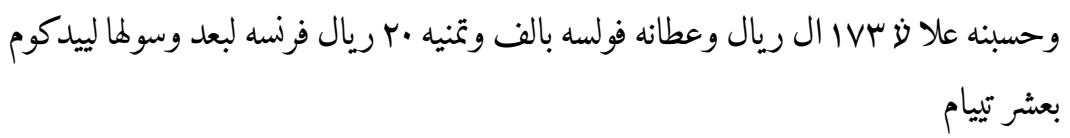

We calculated that the value was 173 per riyāl and we gave (him) a sum of one thousand and eight and 20 French riyäl (to be cashed) after its arrival into your hands in ten days.

T-S 13J25.24, col. 1, 42-col.2, 2. KHAN 2006: 46

\subsubsection{Purposive Adverbial Clauses}

Purposive adverbial clauses seldom occur in the eighteenth/nineteenth-century letter corpus. Complex subordinators introducing this type of adverbial clause are also rare. The following example (42) contains the only instance known to me in which a complex adverbial subordinator occurs. However, due to the physical state of the manuscript, the clause introduced by the subordinator is unfortunately lost:

71 Here, the $t \bar{a}^{\prime}$ marbūta ending is omitted from the first term ('ten') of the construct state and is attached instead to the second term ('days') and written phonetically. This occurs frequently in Modern Cairene Arabic (Abdel-Massih, Abdel-Malek and Badawi, A Reference Grammar of Egyptian Arabic, 8o-81). 


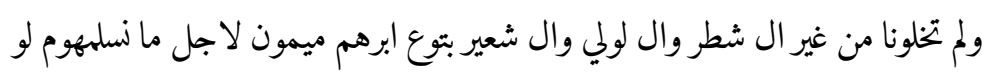

And you should not leave us without the share - the pearls and the barley belonging to Abraham Maimon - so that (we may give it) to him.

Rylands L192, 1 margin 1-2

\section{5}

Conclusion

Through the study of adverbial subordination in roughly contemporaneous adaptations of a folk tale common to both Muslim Middle Arabic and JudaeoArabic, this paper questions the tendency, prevalent in contemporary scholarship, to examine confessional varieties of Middle Arabic in isolation to one another. While this study is limited in scope, it demonstrates that temporal and purposive adverbial clauses occur far more frequently in the Muslim Middle Arabic and Judaeo-Arabic folk tales, than in two genres of Judaeo-Arabic. In exploring the subordinators used to introduce adverbial clauses, however, the preference evident in Judaeo-Arabic folk tales for complex subordinators distinguishes the Judaeo-Arabic texts from their Muslim Middle Arabic counterparts. This paper constitutes a minor study of the extent of linguistic variation between two confessional varieties of Middle Arabic on the level of subordination.

\section{Acknowledgments}

I am deeply indebted to Prof. Geoffrey Khan for his generosity and encouragement during the process of writing this paper, and for his careful proof-reading of earlier drafts. That being said, any errors herein are mine alone.

\section{Bibliography}

Aarts, Bas, "Subordination," Encyclopedia of Language and Linguistics, ed. Keith Brown et al., 2nd ed. Amsterdam: Elsevier, 2006, pp. 248-254.

Abdel-Massih, Ernest T., Abdel-Malek, Zaki N., and Badawi, El-Said M., A Reference Grammar of Egyptian Arabic, Washington, DC: Georgetown University Press, 2009. 
Bernstein, Marc S., Stories of Joseph. Narrative Migrations Between Judaism and Islam, Detroit, Michigan: Wayne State University Press, 2006.

Blau, Joshua, A Grammar of Christian Arabic Based Mainly on South-Palestinian Texts of the First Millennium, Louvain: Secrétariat du CorpusSCO, 1966-1967.

Blau, Joshua, The Emergence and Linguistic Background ofJudaeo-Arabic: A Study of the Origins of Middle Arabic, Jerusalem: Ben-Zvi Institute, 1981.

Blau, Joshua, A Handbook of Early Middle Arabic, Jerusalem: Hebrew University of Jerusalem, 2002.

Brakel-Papenhuyzen, Clara, "The Tale of the Skull: An Islamic Description of Hell in Javanese," Journal of the Humanities and Social Sciences of Southeast Asia, 158/1 (2002), pp. 1-19.

Connolly, Magdalen M., "A Nineteenth-Century Egyptian Judaeo-Arabic Folk Narrative: Text, Translation and Grammatical Notes," Studies in Semitic Linguistics and Manuscripts, ed. Nadia Vidro et al., Uppsala: University of Uppsala Press, 2018(a), pp. 392-420.

Connolly, Magdalen M., "Linguistic Variation in Egyptian Judaeo-Arabic Folk Tales and Letters from the Ottoman Period," Ph.D. thesis, University of Cambridge, 2018(b).

Edzard, Lutz, "Linguistic and Cultural Features of an Iraqi Judeo-Arabic Text of the Qișaș al-'Anbīyā' Genre," Middle Arabic and Mixed Arabic:Diachrony and Synchrony, ed. Liesbeth Zack and Arie Schippers, Leiden: Brill, 2012, pp. 83-94.

Fischer, Wolfdietrich, A Grammar of Classical Arabic: Translated from German by Jonathon Rodgers, New Haven: Yale University Press, 2002.

Häcker, Martina, Adverbial Clauses in Scots: A Semantic-Syntactic Study, Berlin: De Gruyter Mouton, 1999.

Hary, Benjamin H., "Middle Arabic: Proposals for New Terminology," Al-Arabiyya 22 (1989), pp. 19-36.

Hary, Benjamin H., Multiglossia in Judeo-Arabic: With an Edition, Translation and Grammatical Study of the Cairene Purim Scroll, Leiden: Brill, 1992.

Hary, Benjamin H., "Adaptations of Hebrew Script," The World's Writing Systems, ed. Peter T. Daniels and William Bright, Oxford: Oxford University Press, 1996, pp. 727734 .

Hary, Benjamin H., "On Later and Modern Egyptian Judaeo-Arabic," Humanism, Culture, and Language in the Near East: Studies in the Honor of Georg Krotkoff, ed. Asma Afsaruddin and A.H. Mathias Zahniser, Winona Lake, IN: Eisenbrauns, 1997(a), pp. 199-224.

Hary, Benjamin H., "The Impact of the Cairo Genizah Documents on the Study of the History of Arabic," Bulletin of the Israeli Academic Center in Cairo 21 (1997(b)), pp. 3540.

Hary, Benjamin H., "Egyptian Judeo-Arabic Sharh-Bridging the Cultures of Hebrew and Arabic," Judaism and Islam: Boundaries, Communication and Interaction Essays 
in Honour of William M. Brinner, ed. Benjamin H. Hary, John L. Hayes and Fred Astren, Leiden: Brill, 200o, pp. 395-407.

Hary, Benjamin H., Translating Religion: Linguistic Analysis ofJudeo-Arabic Sacred Texts from Egypt, Leiden: Brill, 2009.

Hary, Benjamin H., "Cairo Collection," Encyclopedia of Jews in the Islamic World, ed. Norman Stillman, Leiden: Brill, 2010, pp. 533-534.

Hary, Benjamin H., "Judeo-Arabic as a Mixed Language," Middle Arabic and Mixed Arabic: Diachrony and Synchrony, ed. Liesbeth Zack and Arie Schippers, Leiden: Brill, 2012, pp. 125-144.

Hasson Kenat, Rachel, "The Story of Zayd and Kaḥlā’-A Folk Story in a Judaeo-Arabic Manuscript," Middle Arabic and Mixed Arabic: Diachrony and Synchrony, ed. Liesbeth Zack and Arie Schippers, Leiden: Brill, 2012, pp. 145-156.

Hasson Kenat, Rachel, "New Manuscripts in Late Judaeo-Arabic from the Firkovich Collection," Ph.D. thesis, Hebrew University of Jerusalem, 2016 (in Hebrew).

den Heijer, Johannes, "On Language and Religious Identity: The Case of Middle Arabic, with Special Reference to Christian Arab Communities in the Medieval Middle East," High vs. Low and Mixed Varieties: Status, Norms and Functions Across Time and Languages, ed. Gunvor Mejdell and Lutz Edzard, Weisbaden: Harrassowitz, 2012, pp. $53^{-87}$.

Hinds, Martin and Badawi, El-Said M., A Dictionary of Egyptian Arabic: Arabic-English, Beirut: Librarie du Liban, 1986.

Khan, Geoffrey, "Notes on the Grammar of a Late Egyptian Judaeo-Arabic Text," Jerusalem Studies in Arabic and Islam 15 (1992), pp. 220-239.

Khan, Geoffrey, "A Judaeo-Arabic Commercial Letter from Early Nineteenth Century Egypt," Ginzei Qedem 2 (2006), pp. 37-58.

Khan, Geoffrey, "Judaeo-Arabic," Encyclopedia of Arabic Language and Linguistics, ed. Kees Versteegh et al., Leiden: Brill, 2007, pp. 526-536.

Khan, Geoffrey, "Middle Arabic," The Semitic Languages: An International Handbook, ed. Stefan Weninger et al., Berlin: De Gruyter Mouton, 2012, pp. 817-835.

Khan, Geoffrey, "A Judaeo-Arabic Document from Ottoman Egypt in the Rylands Genizah Collection," From Cairo to Manchester:Studies in the Rylands Genizah Fragments, ed. Renate Smithuis and Philip S. Alexander, Oxford: Oxford University Press on behalf of University of Manchester, 2013, pp. 233-248.

van Koningsveld, Pieter S., "Arabica-Islam," Bibliotheca Orientalis 36/1 (1978), pp. 93-94. Kortmann, Bernd, Adverbial Subordination: A Typology and History of Adverbial Subordinators Based on European Languages, Berlin: De Gruyter, 1997.

Lentin, Jerome, "Middle Arabic," Encyclopedia of Arabic Language and Linguistics, ed. Kees Versteegh et al., Leiden: Brill, 2008, pp. 215-223.

Lentin, Jerome, and Grand'Henry, Jacques, Moyen arabe et variétés mixtes de l'arabe à travers l'histoire, Leuven: Peeters Press, 2008. 
Mejdell, Gunvor, "Playing the Same Game? Notes on Comparing Spoken Contemporary Mixed Arabic and (Pre)Modern Written Middle Arabic," Middle Arabic and Mixed Arabic: Diachrony and Synchrony, ed. Liesbeth Zack and Arie Schippers, Leiden: Brill, 2012, pp. 235-246.

Olson, Michael L. "Barai Clause Junctures: Towards a Functional Theory of Interclausal Relations," Ph.D. thesis, Australian National University, 1981.

Ørum, Olav G., 'Ușșit il-Gumguma or 'The Story of the Skull': With Parallel Versions, Translation and Linguistic Analysis of Three 1gth-century Judaeo-Arabic Manuscripts from Egypt, Leiden: Brill, 2017.

Palva, Hekki, "A 17th-18th Century Manuscript in Spoken Egyptian Arabic: Part One: Text and Translation," Le Muséon 120/3-4 (2007), pp. 395-433.

Palva, Hekki, "A 17th-18th Century Manuscript in Spoken Egyptian Arabic: Part Two: Linguistic Notes," Le Muséon 121/1-2 (2008), pp. 93-123.

Pennacchietti, Fabrizio A., “'Il racconto di Giomgiomé' di Faridoddìn Attàr e le sue fonti cristiane," Orientalia Christiana Periodica 62/1 (1996), pp. 89-119.

Pennacchietti, Fabrizio A., "Versioni cristiane e guidaide di una leggende islamica," Redefining Christian Identity: Cultural Interaction in the Middle East Since the Rise of Islam, ed. Jan J. van Ginkel, et al., Leuven: Uitgeverij Peeters en Departement Oosterse Studies, 2005, pp. 293-299.

Popa, Ecaterina, "Non-finite and Verbless Clauses: Textual Values," RRL LIII 3 (2008), pp. 329-339.

Thompson, Sandra A., Longacre, Robert E., and Hwang, Shin J.J., "Adverbial clauses," Language Typology and Syntactic Description, ed. Timothy Shopen, Cambridge: Cambridge University Press, [1985] 2007, pp. 237-300.

Tottoli, Roberto, "The Story of Jesus and the Skull in Arabic Literature: The Emergence and Growth of a Religious Tradition," Jerusalem Studies in Arabic and Islam 28 (2003), pp. 222-259.

Van Valin, Robert D., "A Typology of Syntactic Relations in Clause Linkage," Proceedings of the Tenth Annual Meeting of the Berkeley Linguistics Society, ed. Claudia Brugman and Monica Macaulay, Berkeley, CA: Berkeley Linguistics Society, 1984, pp. 542-558.

Wagner, Esther-Miriam, Linguistic Variety of Judaeo-Arabic in Letters from the Cairo Genizah, Leiden: Brill, 2010.

Wagner, Esther-Miriam, "Subordination in 15th- and 16th-Century Judeo-Arabic," Journal of Jewish Languages 2 (2014), pp. 143-164.

Zack, Liesbeth, and Schippers, Arie, Middle Arabic and Mixed Arabic: Diachrony and Synchrony, Leiden: Brill, 2012.

OED online. June 2017. (Oxford). http://www.oed.com/ 